\title{
论 文
}

\section{川滇南北向构造带早中生代构造变形研究}

\author{
陈虹 ${ }^{(1)}$, 胡健民 ${ }^{(1 *}$, 渠洪杰 ${ }^{(1)}$, 武国利 ${ }^{(2)}$ \\ (1) 中国地质科学院地质力学研究所, 北京 100081 ; \\ (2) 中国科学院地质与地球物理研究所, 北京 100029 \\ * 联系人, E-mail: jianminhu@ vip.sina.com \\ 收稿日期: 2010-11-21; 接受日期: 2011-04-15 \\ 国家自然科学基金(批准号: 40872135, 40830314)资助
}

\begin{abstract}
摘要贺兰-川滇南北向构造带是划分中国大陆东西的地幔陡变带, 其南段川滇南北 向构造带是由几个性质不同的构造系统叠加组成的复杂构造带. 研究发现, 位于扬子 地块西缘的川滇南北向构造带发育由赝行状左行走滑断裂为骨架的走滑构造带. 走滑 构造带经历了两期构造叠加, 早期变形为北东-南西挤压应力场形成的一系列北西-南东 走向的逆冲断裂, 晚期北西-南东挤压应力场环境下沿先前的逆冲断层形成一系列左行 走滑断裂. 在这些左行走滑断裂之间, 发育一些中生代盆地, 盆地沉积相和古流向研究 显示, 这些盆地的形成受走滑断裂控制. 因此, 依据盆地内最老地层限定, 扬子西缘走 滑构造带形成于早中生代. 作者认为, 这个走滑构造带的形成, 很可能与晚三叠世-侏 罗纪时期扬子地块顺时针旋转并持续向北俯冲一碰撞有关, 川滇南北向构造带在早中生 代中国大陆的主体碰撞拼贴过程中就已经开始形成.
\end{abstract}

\section{关键词}

川滇南北向构造带

扬子地块西缘

早中生代构造变形

中生代盆地

左行走滑断裂
中国大陆中部贺兰-川滇南北向构造带沿鄂尔 多斯盆地和四川盆地西缘的贺兰山-龙门山-攀西一 带展布, 深部地球物理特征显示出明显的带状延伸 特点 ${ }^{[1,2]}$. 该构造带中下地壳约 $20 \mathrm{~km}$ 深处的低速带 特征 ${ }^{[2]}$ 与磁力异常、布格重力异常、重力梯度带对 应, 具有明显地幔陡变带的特点 ${ }^{[1,3]}$, 与中国大陆内 部新生代最强烈的活动构造带和南北地震带相对 应 $^{[4 ~ 6]}$. 因此, 一些地质与地球物理学家认为存在划 分中国岩石圈及大陆构造一级构造单元的南北向 构造带 ${ }^{[3,7 \sim 9]}$.

川滇南北向构造带被认为是现今划分扬子地块 和松潘-甘孜地体的界限, 与青藏高原的隆升和向东 挤出相关, 目前的研究主要集中于新生代构造 ${ }^{[10 ~ 15]}$.
尤其是汶川地震发生后, 作为中国最重要地震带的 组成部分, 川滇南北向构造带活动构造特征、变形 机制、变形速率、位移场等受到学术界高度重视 ${ }^{[16]}$. 中国南北大陆最终碰撞时代为印支期, 扬子地块西 缘应该对这次重要的俯冲、碰撞事件有所响应 ${ }^{[8]}$. 一 些学者曾经提出川滇南北向构造带最初形成于印支 期的观点 ${ }^{[8,17,18]}$, 但目前为止, 还没有获得具体的地 质证据. 本文通过对川滇南北向构造带研究发现, 扬 子地块西缘发育一系列北西-北北西向左行走滑断裂, 它们控制了晚三叠世-侏罗纪盆地的发育, 表明川滇 南北向构造带很可能在早中生代就已经开始发育, 而且与中国南北大陆的碰撞以及扬子地块的旋转存 在密切的联系.

英文引用格式: Chen H, Hu J M, Qu H J, et al. Early Mesozoic structural deformation in the Chuandian N-S Tectonic Belt, China. Sci China Earth Sci, 2011, doi: 10.1007/s11430-011-4261-7 


\section{1 地质构造背景}

川滇南北向构造带位于扬子地块与松潘-甘孜地 体之间, 是由松潘-甘孜地体东缘逆冲构造带(木里推 覆体、盐源推覆体)、扬子地块西缘左行走滑系统以 及西南部楚雄盆地等组成的复杂构造带(图 1). 构造 带东侧扬子地块地壳厚度为 30 45 km, 等值线呈北 北东走向, 上地壳具有正常的速度分布特征, 而且 Moho 面的壳幔耦合为简单的一级间断. 西侧的松潘甘孜地体地壳厚度为 45 75 km, 等值线为近东西向, 其上地壳存在低速层, 而且壳幔耦合为复杂的高、低 速相间的多层壳幔过渡带 ${ }^{[19,20]}$. 基于新生代以来断 层和块体位移的 GPS 监测所恢复的构造应力场显示,
现今中国大陆的总体格局表现为以南北向构造带为 界西部挤压、东部伸展的特征 ${ }^{[6,7]}$.

松潘-甘孜地体东缘具有明显的扬子型基底，上 覆震旦纪-早古生代滨海相碎屑岩、晚古生代台地相 碳酸盐岩、三叠纪巨厚的复理石沉积和古近纪陆相碎 屑岩. 松潘-甘孜地体经历了印支期褶皱加厚和滑脱 构造 ${ }^{[21 ~ 23]}$, 并在白严纪时期形成了地体边缘的低角 度逆冲推覆构造系统 ${ }^{[24,25]}$. 而且, 松潘-甘孜地体内 还广泛发育有印支和喜马拉雅期同构造侵位的花岗 岩[21,22].

扬子地块西缘主要为中上元古界和新元古代晚 期花岗岩组成的扬子型基底与晚震旦纪-白严纪地层 组成的盖层沉积(图 2). 晚古生代-早中生代时期, 古

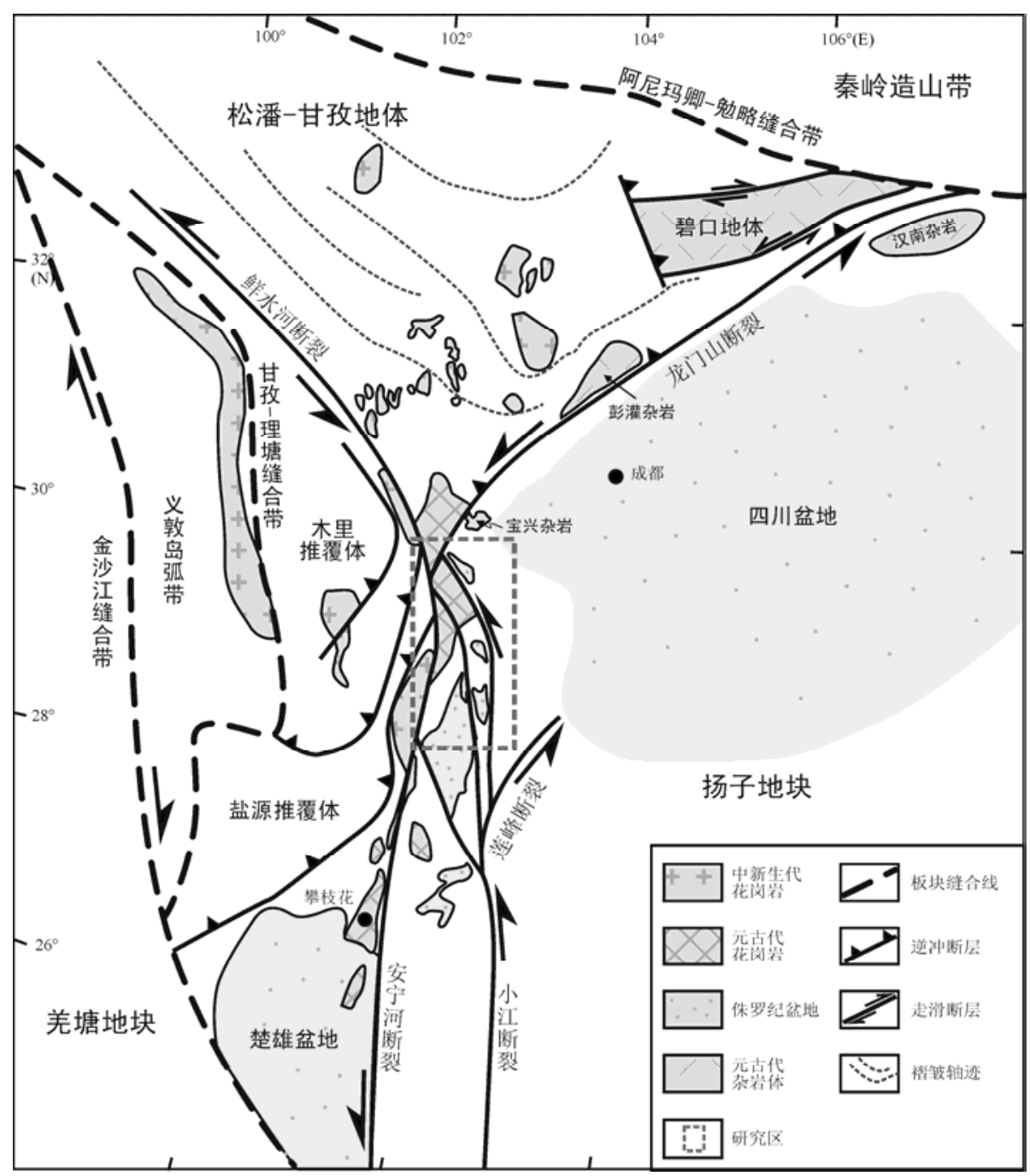

图 1 川滇南北向构造带区域构造特征 


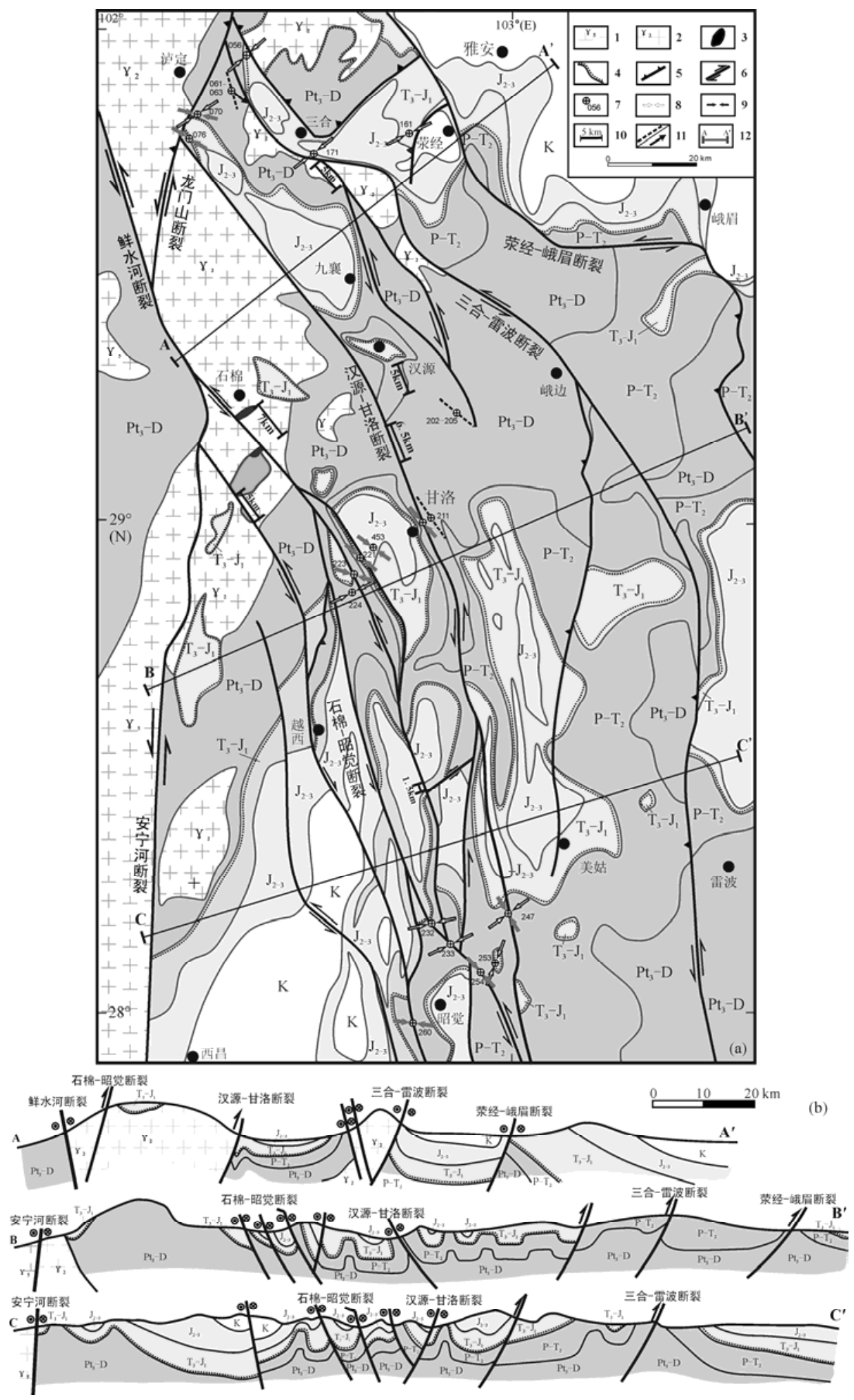

图 2 川滇南北向走滑构造带地质构造简图(a)及构造剖面图(b)

1. 中生代花岗岩; 2. 晚元古代花岗岩; 3. 超基性岩; 4. 不整合界线; 5. 逆冲断层; 6. 走滑断层; 7. 构造观察点和点号; 8. 北东-南西向主压应 力方位; 9. 北西-南东向主压应力方位; 10. 走滑位移及距离; 11. 构造面理走向/矿物线理倾伏向; 12. 构造剖面位置 
特提斯洋经历了打开-扩张-消亡的完整过程, 扬子地 块西缘一直处于被动大陆边缘环境, 形成了连续的 边缘台地相盖层沉积. 早中生代开始的碰撞造山导 致一些晚三叠世-侏罗纪陆相沉积盆地和白严纪陆内 前陆盆地沉积 ${ }^{[26]}$. 扬子地块西缘现今发育一系列总 体呈北西走向的断层, 主要包括安宁河断裂、小江 断裂及大凉山断裂系 ${ }^{[27]}$ 等, 均以左行走滑变形为主 (图 1). 走滑构造带断裂具有强烈的新生代活动特征, 并且形成了一系列与断裂走滑相关的新生代盆地 ${ }^{[27]}$.

\section{2 扬子地块西缘走滑断裂带构造特征与构 造应力场}

扬子地块西缘大凉山断裂系位于安宁河断裂以 东、小江断裂以北, 主要由四条断裂组成: 石棉-昭觉 断裂、汉源-甘洛断裂、三合-雷波断裂和䓠经-峨眉山 断裂(图 2(a)). 断裂系北段整体呈北西走向, 切穿了 新元古代花岗岩及中三叠世以前地层单元, 同时明 显控制了中生代盆地发育, 最北端被龙门山断裂逆 掩(图 2(a)). 南段走向整体以近南北向为主, 并且错 断的最新地层是白严系, 断裂最南端均与莲峰断裂 斜交(图 1). 断裂系最北端的宝兴杂岩逆冲于中生代 地层之上, 可能是晚期滑塌形成 ${ }^{[28]}$. 断裂系在剖面上 显示出明显的 “正花状” 构造形态, 是典型的走滑断 裂组合特征(图 2(b)), 而且断裂间构造岩片内晚三叠 世以前地层呈隔档式褶皱形态(图 2(b)).

\section{1 石棉-昭觉断裂}

石棉-昭觉断裂北段与鲜水河断裂相连, 南段与 小江断裂相连, 南北延伸约 $250 \mathrm{~km}$. 主断裂的南西 侧发育有三条北西-近南北向的次级断裂(图 2(a)).

石棉-昭觉断裂的北段错断晚元古代花岗岩和超 基性岩体, 表现为一组密集的构造透镜体化变形带. 断裂带内构造透镜体排列特征(图 3(a))及 Sc 面上的擦 痕线理显示逆冲断裂特征, 恢复的主压应力方位为北 东 - 南西向, $\sigma_{1}=241^{\circ} \angle 39^{\circ}, \sigma_{2}=334^{\circ} \angle 4^{\circ}, \sigma_{3}=70^{\circ} \angle$ $47^{\circ}$ (图 3(b)). 计算古构造应力场的 StereoNett 软件由 德国鲁尔大学开发(Johannes Duyster, http://www.ruhruni-bochum.de/hardrock/downloads.Htm, 2000). 同时, 超基性岩体的错开方式显示断裂还具有明显的左行 走滑特征(图 2(a)).

中段主断裂和次级断裂多沿河流延伸, 断裂面

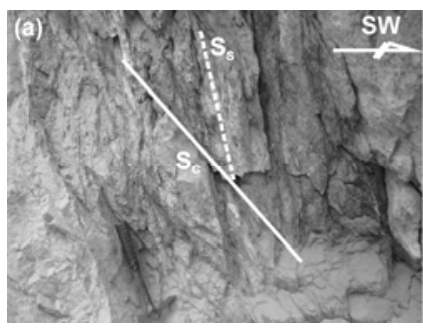

(b)

\section{图 3 扬子地块西缘石棉-昭觉断裂带内 S-C 组构(a)及断层 面 $(\mathbf{S c})$ 上擦痕线理恢复的主压力方位 $(\mathbf{b})$ 石棉县安顺场}

倾向北东, 倾角达 $70^{\circ}$ 左右. 断层使得震旦系白云岩 与侏罗系紫红色泥岩、泥盆系灰岩和砂岩、二叠系玄 武岩等直接接触. 破碎带内白云岩和灰岩中的擦痕 线理指示断裂具有左行走滑特征, 主压应力方位为 北西-南东向(图 4(a)). 有时在断裂西盘二叠系玄武岩 中还残留有早期右行逆冲断层, 断层产状为 $280^{\circ} \angle$ $50^{\circ}$, 主应力方位 $\sigma_{1}=242^{\circ} \angle 17^{\circ}, \sigma_{2}=342^{\circ} \angle 30^{\circ}, \sigma_{3}=$ $129^{\circ} \angle 56^{\circ}$ (图 4(b)).

南段错断的最新地层是白严系, 代表断层晚期活 动叠加. 断层面特征及破碎带中灰岩和砂岩的构造透 镜体内发育的擦痕显示为左行走滑特征(图 5(a)), 主 压应力方位为北西-南东向(图 4(c) (f)). 露头上常可见 到与左行走滑断层共轭发育的右行走滑断层(图 5(b)), 后者发育程度远不如左行走滑断层, 两组断层的擦痕 联合反演确定的应力场方向可能更接近实际, 主应力 方位 $\sigma_{1}=68^{\circ} \angle 13^{\circ}, \sigma_{2}=228^{\circ} \angle 76^{\circ}, \sigma_{3}=338^{\circ} \angle 5^{\circ}$ (图 4(g)).

\section{2 汉源-甘洛断裂}

汉源-甘洛断裂沿泸定二郎山-汉源-甘洛-昭觉延 伸约 $280 \mathrm{~km}$, 甘洛以北呈北西-南东方向, 往南呈北 北西-南南东方向.

甘洛以北新元古代花岗岩与晚元古代-侏罗纪不 同时代地层断层接触，断层面向西或者向东高角度 倾斜, 断裂破碎带宽度约 $200 \mathrm{~m}$. 花岗质构造角砾岩 角砾砾径约 1 2 cm, 灯影组白云岩呈岩溶角砾岩状 产出. 断层面上发育的擦痕显示两期叠加, 早期断层 阶步、擦痕、方解石生长线理以及断层两侧牵引褶皱 等均指示逆冲性质(图 5(c)), 主应力方位 $\sigma_{1}=238^{\circ} \angle$ $25^{\circ}, \sigma_{2}=332^{\circ} \angle 11^{\circ}, \sigma_{3}=86^{\circ} \angle 65^{\circ}$ (图 4(h)); 晚期断层面 切断早期断层面, 断层面上阶步、擦痕和方解石生长 线理指示为左行走滑(图 5(c)), 主压应力方位为北西南东向(图 4(i) (k)). 

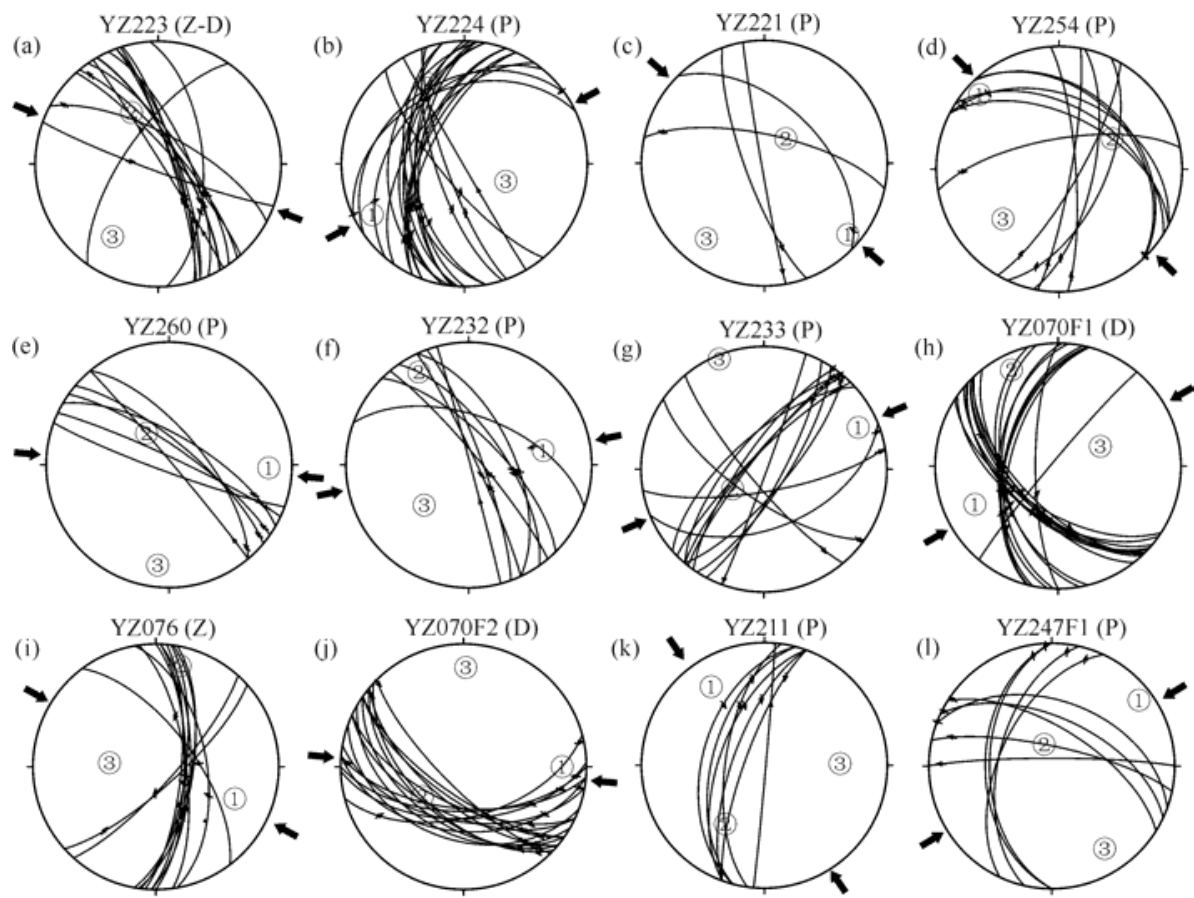

(k)
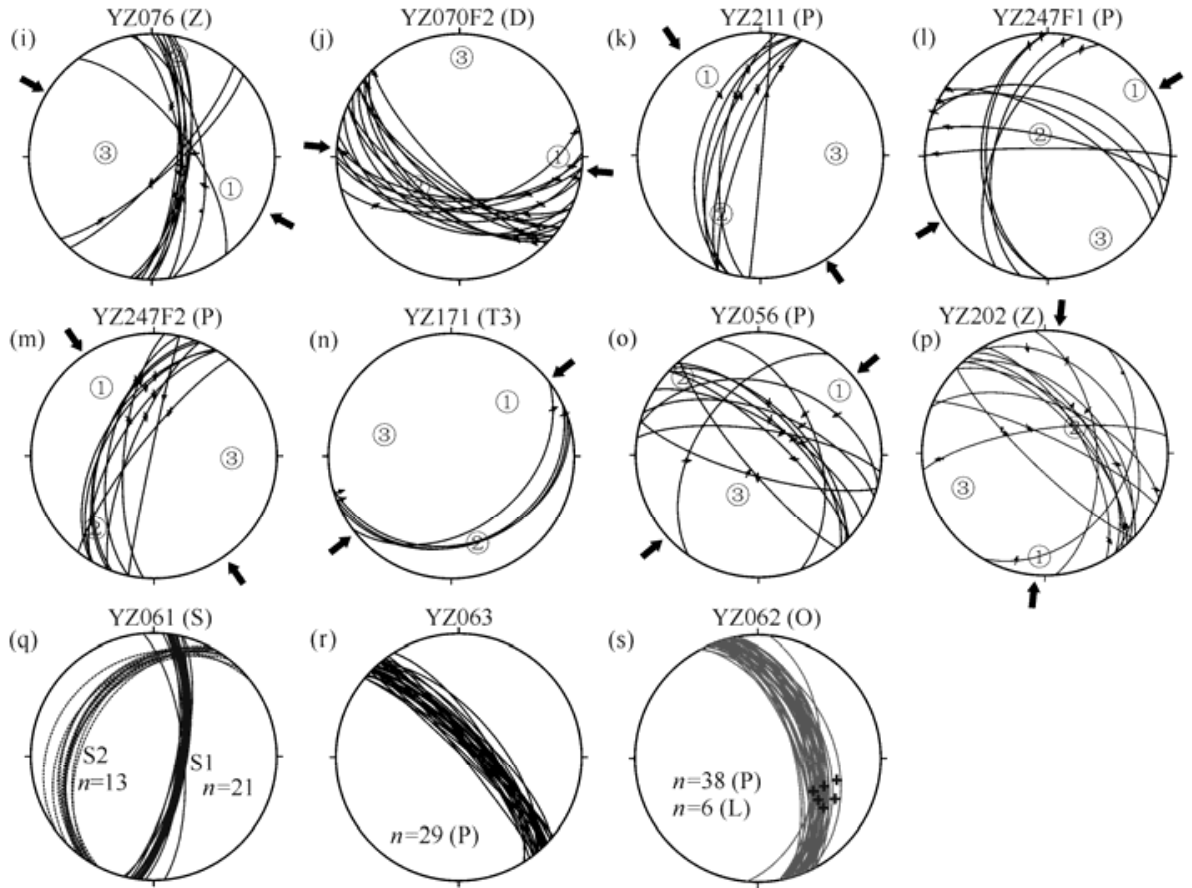

图 4 扬子地块西缘走滑断裂带断层主应力方位及构造面理赤平投影图

所有投影均为等面积下半球投影. YZ223(Z-D), 野外观察点号及地层时代; F1, 早期断层; F2, 晚期断层; (1) $\sigma_{1} ;$ (2) $\sigma_{2} ;$ (3) $\sigma_{3} ; P$, 构造面理; $\mathrm{L}$, 矿物线理

断裂向南延伸到美姑河附近，断层面总体产状 $260^{\circ} \angle 60^{\circ}$, 二叠系玄武岩逆冲在晚三叠-早侏罗世砂 岩及泥岩之上. 早期断层具有共轭断层面, 断层面上 的擦痕线理具有走滑特点, 其主应力方位 $\sigma_{1}=57^{\circ} \angle 1^{\circ}$, $\sigma_{2}=325^{\circ} \angle 67^{\circ}, \sigma_{3}=151^{\circ} \angle 23^{\circ}$ (图 4(1)), 晚期断层面上 新生绿帘石矿物线理指示断层具有明显的左行逆冲性 质(图 5(d)), 主压应力方位为北西-南东向(图 4(m)).

\section{3 三合-雷波断裂}

三合-雷波断裂沿䓠经县三合乡-峨边县-雷波县
西侧延伸约 $300 \mathrm{~km}$ ，总体呈向北东突出的弧形. 断 裂北段宏观构造特征与汉源-甘洛断裂北段基本相同. 由于植被原因，主断层面很难见到．相应的构造应力 场方位通过断层两侧一些次级断层面及其擦痕确定, 恢复出的主应力方位与本期变形的区域应力场方位 一致. 如断层北东盘晚三叠世砂岩发育顺层面擦痕, 层面产状为 $150^{\circ} \angle 25^{\circ}$, 擦痕倾伏向 $70^{\circ}$ 或 $250^{\circ}$, 倾伏 角 $2^{\circ} \sim 10^{\circ}$, 主压应力方位为南西-北东向(图 4(n)); 宝 兴杂岩体西南边界断层产状为 $45^{\circ} \angle 70^{\circ}$, 主应力方 位 $\sigma_{1}=50^{\circ} \angle 26^{\circ}, \sigma_{2}=316^{\circ} \angle 9^{\circ}, \sigma_{3}=208^{\circ} \angle 62^{\circ}$ (图 4(o)). 

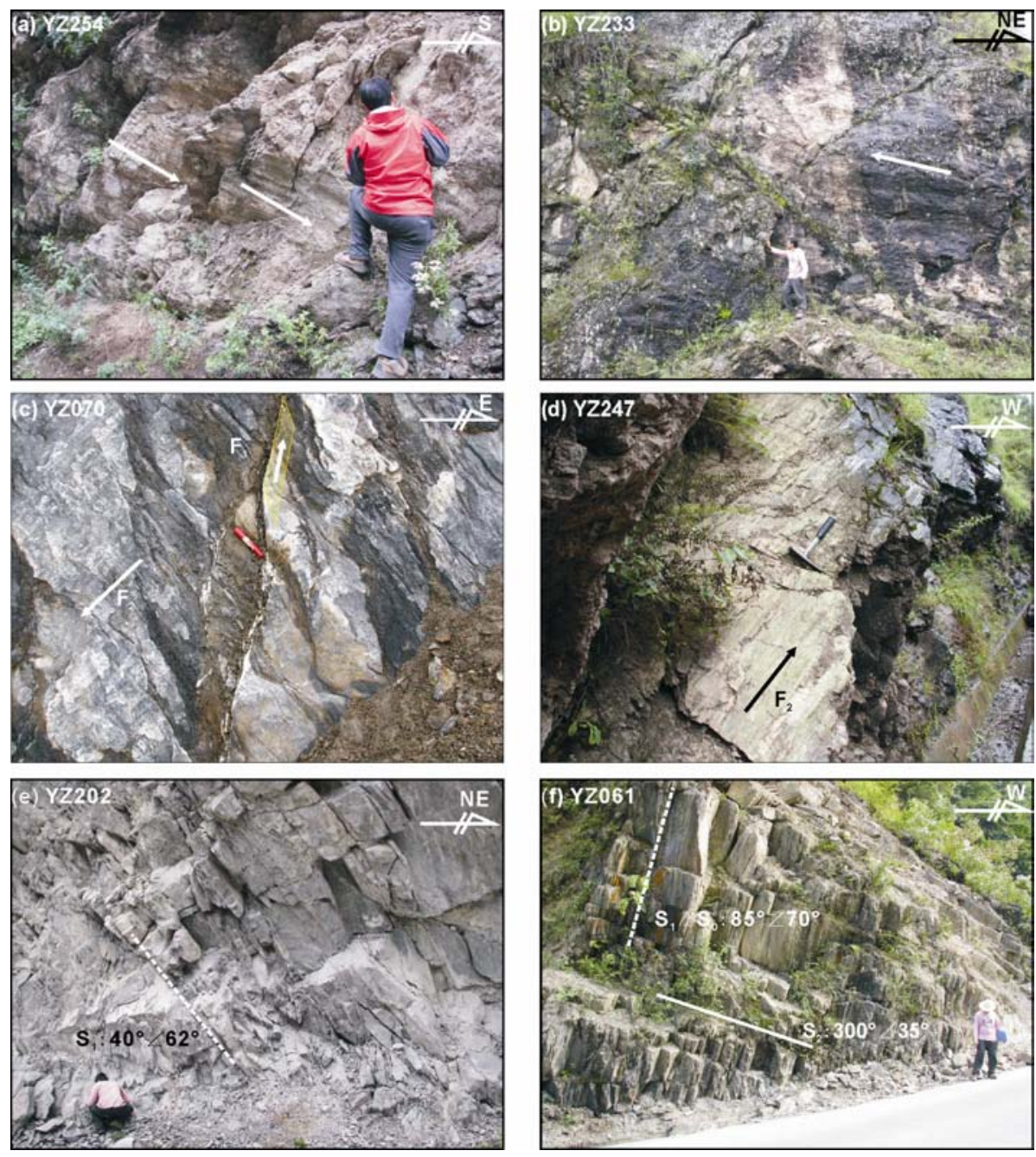

图 5 扬子地块西缘走滑断裂带构造变形与面理置换特征

(a) 石棉-昭觉断裂带南段左行走滑断层及擦痕线理(昭觉县); (b) 石棉-昭觉断裂带南段右行走滑断层及擦痕线理(昭觉县); (c) 汉源-甘洛断 裂带泥盆系灰岩中断层叠加 (二郎山收费站); (d) 汉源-甘洛断裂带二叠系玄武岩中断层叠加(美姑县); (e) 构造岩片内震旦系火山碎屑岩中辟 理置换层理(甘洛县北东); (f) 构造岩片内志留系粉砂质泥岩中两组面理置换(二郎山)

\section{4 主干断裂间构造岩片变形特征}

上述走滑断裂将扬子地块西缘台地沉积和早期 岩浆结晶基底切割成几个北西-南东向展布的构造岩 片. 尽管这些构造岩片内变形相对简单，但同样记录 了与主断层相应的变形过程.

\subsection{1 挤压缩短构造变形}

构造岩片内常常发育密集䢃理面强烈置换层理 的构造现象, 显示轴面陡倾的紧闭褶皱发育. 震旦 系火山碎屑岩中密集破䢃理强烈置换层理(图 5(e)), 䢃理面上发育斜向逆冲擦痕显示主压应力方位为北
北东-南南西向(图 4(p)). 奥陶-泥盆纪及三叠纪地层 中也发育了两组构造面理的叠加, 其中早期面理总 体呈北西-南东走向, 而且多平行于原生层理面, 晚 期面理近直交置换早期面理和层理(图 4(q)，4(r), $5(\mathrm{f}))$.

走滑断层之间的构造岩片中褶皱相对简单，主 要是一些核部相对宽缓的箱状褶皱等(图 2(b)，6(a)). 褶皱的轴面一般倾向南西, 褶坡地层多为三叠系灰 岩和砂岩. 有时见到下伏二叠纪玄武岩中发育强烈 的䢃理化, 䢃理产状为 $213^{\circ} \angle 50^{\circ}$, 反映了南西-北东 向挤压构造应力场环境特征(图 6(b)). 

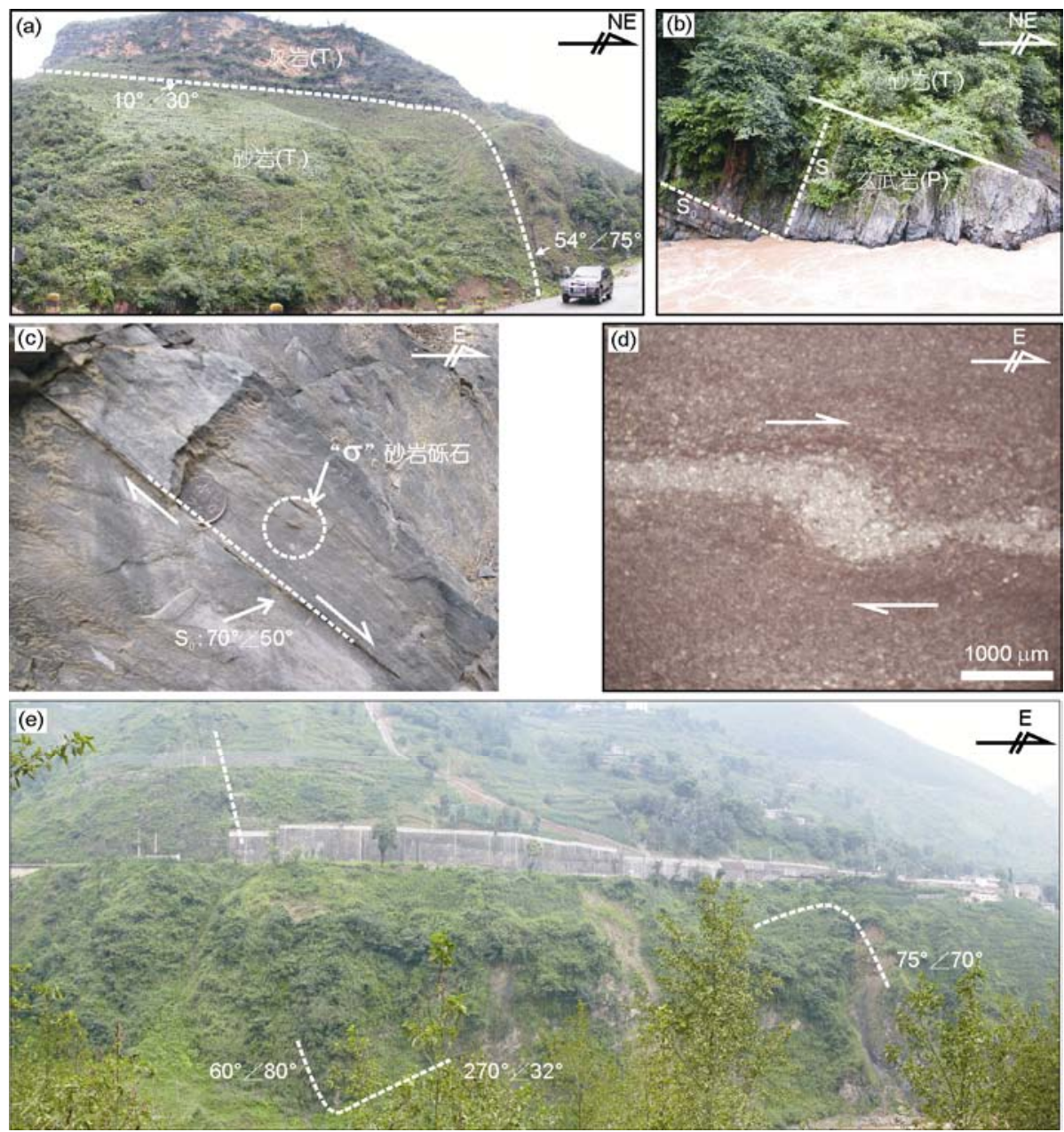

图 6 扬子地块西缘走滑断裂带内二叠纪-晚三叠世地层构造变形特征

(a) 下三叠统箱状褶狓(美姑县西); (b) 二叠纪玄武岩中的䢃理(美姑县西); (c) 下三叠统褶皱东翼的顺层剪切变形野外特征(汉源县福乡); (d) 上三叠统褶䏢西翼的顺层剪切变形显微特征(汉源县福乡); (e) 上三叠统砂岩中的尖棱褶皱(甘洛县嘎日乡)

在汉源县福乡附近，褶皱的晚三叠世地层中保 存有明显的顺层剪切变形. 而且, 褶皱东翼粉砂岩中 砂岩砾石的不对称旋转特征(图 6(c))和西翼不对称褶 皱(图 6(d))均显示了由西往东剪切滑动的特征，也证 明褶皱形成前已经存在顺层的剪切变形.

中生代盆地内晚三叠世地层中褶皱以宽缓的箱 状褶皱、不对称的尖棱状褶皱为主(图 6(e))，地层中的 断层具有明显的断坪-断坡组合特点, 断层的走向也 与两侧的走滑断层近平行. 这些断层和褶皱表明中生 代盆地在晚三叠世以后仍然经历了滑脱构造变形.

在走滑断裂附近, 褶皱相对紧闭. 如汉源-甘洛 断裂附近, 志留系砂岩、粉砂岩中发育 D1 期不对称 褶皱(图 7(a)), 枢纽的倾伏向、倾伏角分别为 $83^{\circ}$ $132^{\circ}$ 和 $6^{\circ} \sim 30^{\circ}$. 发育不对称褶皱的岩层中次级断层 (D2)面上的擦痕显示了逆断层性质, 断层走向与褶 皱枢纽近于平行(图 7(b)), 并且明显切断了褶皱构造 (图 7(a)). 褶皱岩层面上与枢纽近垂直的方解石生长 线理显示褶皱是纵弯挤压下形成(图 7(c)). 如果将岩 层按原始层序复原, 不对称褶皱就清楚地指示由南 西往北东方向逆冲的特征. 在汉源-甘洛断裂靠近龙 门山断裂处, 早古生代地层中发育明显的不对称褶 皱, 也显示由南西往北东方向的逆冲(图 7(d)).

\subsection{2 走滑剪切构造变形}

走滑断裂之间的构造岩片中也记录了区域性左 行走滑剪切变形构造形迹. 两路乡奥陶系弱片理化 
的石英砂岩中, 片理面上发育近水平绢云母矿物线 理, 线理倾伏产状为 $120^{\circ} \angle 30^{\circ}$ (图 4(s)). 显微构造特 征显示新生成的绢云母具有明显的左行剪切变形(图 8(a)).

在安宁河断裂西侧冕宁县附近, 发育一条三叠 纪中酸性岩浆岩体, 花岗岩、花岗闪长岩具有明显的 定向构造, 其构造面理产状为近南北向, 显微构造特 征具有明显的左行剪切变形特征(图 8(b)).

\section{5 中生代位移量估算}

走滑断裂的位移距离可以利用各种标志性地质 体或地层界线的错断来进行估算 ${ }^{[22]}$. 而对于中生代
走滑位移量的估算必须通过中生代之前各种地质标 志的错断进行估算, 并要剔除新生代变形叠加上去 的位移量. 为了排除因逆冲或下滑引起的水平位移 效应, 要尽量选择产状相对陡立的标志体进行估算.

由于已经鉴别出存在早中生代左行走滑变形, 晚三叠世以前地质体被错断的距离实际上是中生代、 新生代走滑变形的综合结果. 根据 1:20 万地质图分

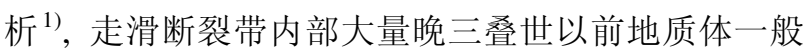
都发生了大于 $5 \mathrm{~km}$ 的位移(图 2(a)). 石棉-昭觉断裂 系主断裂切穿了石棉县附近的超基性岩体，左行位 移距离约 $7 \mathrm{~km}$; 次级断裂左行切断了新元古代花岗岩 中残留的早期火山岩地层，错断距离达 $5 \mathrm{~km}$. 汉源-甘
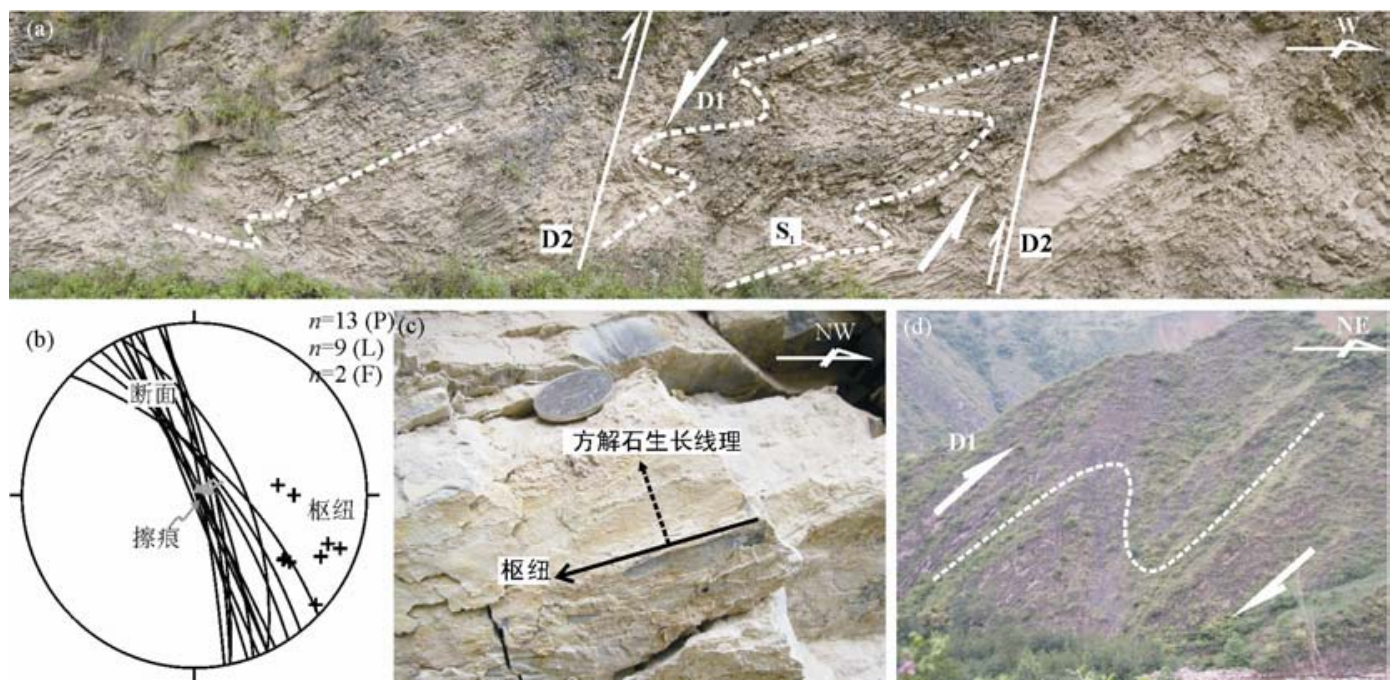

图 7 扬子地块西缘走滑断裂系内早古生代地层构造变形特征

(a) 志留系褶皱与断层构造剖面(甘洛县东); (b) 构造要素赤平投影图; (c) 褶皱枢纽与方解石生长线理; (d) 不对称褶皱(泸定县冷碛镇)
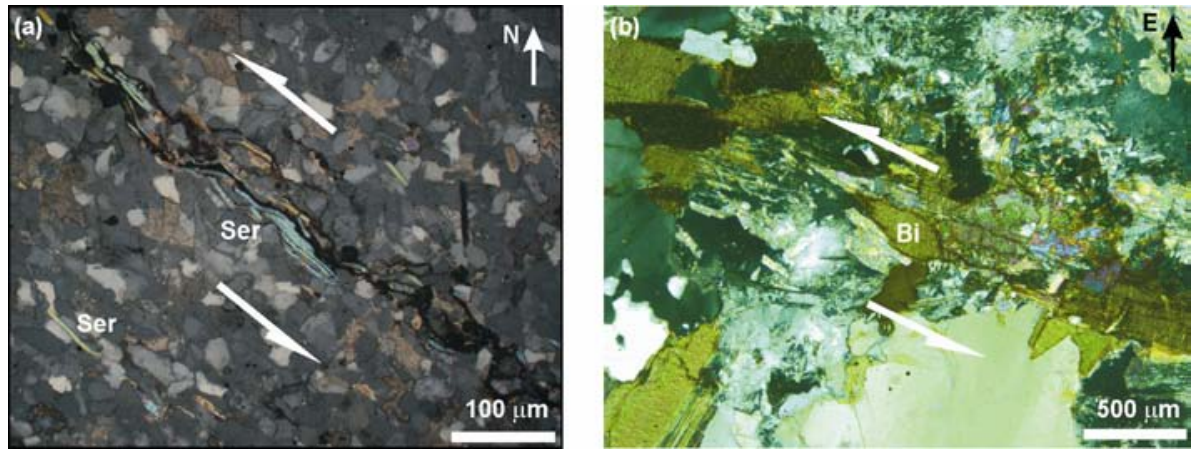

图 8 扬子地块西缘走滑断裂带内走滑构造变形显微构造特征

(a) 奥陶系砂岩中的绢云母定向构造(天全县两路乡); (b) 三叠纪花岗岩中的“云母鱼”构造特征(冕宁县西)

1) 四川省地质局第一区域地质测量队. 石棉幅、冕宁幅、西昌幅、䓠经幅 1:20 万地质图. 1966 1975 
洛主断裂在甘洛北将震旦系与古生界之间的界线左 行错断了约 $6.5 \mathrm{~km}$; 次级断层在汉源南将志留系与 二叠系之间的界线左行错断了约 $5 \mathrm{~km}$. 三合-雷波断 裂南侧新元古代花岗岩边界和火山岩边界走向呈现 明显的波状弯曲, 显示约 $5 \mathrm{~km}$ 的位移. 而在断裂南 段雷波县松树一带, 震旦系灯影组明显左行位移约 3 $\mathrm{km}$. 䓠经-峨眉断裂两侧的二叠系地层在马边县东明 显被左行错断约 $8 \mathrm{~km}$. 整个走滑构造带的位移量大 体相当于几条走滑断层的主断层和次级断层位移量 的总和. 根据上述对晚三叠世以前地质体各断裂左 行位移距离计算, 整个断裂系在中-新生代的左行走 滑位移至少约 $40 \mathrm{~km}$.

石棉-昭觉断裂南段利用水系和洪积扇分布特 征测量出来的走滑位移量为 $3.2 \mathrm{~km}^{[27]}$, 断裂系南部 白严系被左行切开约 $3 \mathrm{~km}$, 中上侏罗统错开 $1.5 \mathrm{~km}$. 大渡河弯转显示汉源-甘洛断裂错断距离约 $3 \mathrm{~km}$. 如果走滑断裂带内其他断裂在新生代的走滑位移也 均按 $3.2 \mathrm{~km}$ 计算, 那么扬子西缘新生代的走滑位移 实际上仅为 $13 \mathrm{~km}$, 而中生代时期的左行位移约为 $27 \mathrm{~km}$.

安宁河断裂、小江断裂和鲜水河断裂是川滇南 北向构造带内最明显的几条走滑断裂, 断裂的位移 量均达到几十公里 ${ }^{[29]}$. 前人研究几乎都认为它们与 新生代青藏高原的隆升和向东的逃逸有关 ${ }^{[10,30 \sim 32]}$. 然而有研究表明, 安宁河断裂在印支期便具有压扭 性左旋特征, 小江断裂更是早古生代以来发育的岩 石圈断裂 ${ }^{[33]}$. 沿着安宁河断裂条带状延伸的燕山期 酸性-中基性侵入体, 就是该走滑断裂在中-晚侏罗 世活动的直接证据. 利用地层和构造特征获得的小 江断裂系的左旋位错最大位移量约为 $63 \mathrm{~km}^{[29]}$, 明 显大于晚新生代时期 $30 \mathrm{~km}$ 的位移量 ${ }^{[34]}$. 所以安宁 河断裂和小江断裂在中生代时期已经具有明显的左行 走滑位移, 其中小江断裂至少在晚第三纪以前已经存 在约 $33 \mathrm{~km}$ 的位移量. 但是, 上述两条断裂的中生代 位移量与鲜水河断裂仍存在明显的差距 ${ }^{[29,30,35]}$, 扬子 西缘走滑断裂带内 4 条断层约 $27 \mathrm{~km}$ 的位移量则正 好弥补了它们之间的差距, 也进一步证明整个川滇 南北向构造带在中生代时期已经存在强烈的走滑构 造变形.

\section{3 变形时代}

由于川滇南北向构造带及整个青藏高原东缘新 生代期间经历了强烈的构造变形, 致使前新生代构造 变形形迹难以鉴定出来. 在中生代, 扬子地块北缘与 华北板块之间处于陆块碰撞拼贴和陆内变形阶段 ${ }^{[36-39]}$. 同时, 扬子地块西缘与芫塘地块也处于碰撞拼贴阶 段 ${ }^{[40]}$, 所以, 作为扬子地块西缘的川滇南北向构造带 沿线, 也应该记录了中生代变形. 松潘-甘孜地体内 大量的中生代花岗岩体的侵位充分地表明, 川滇南 北向构造带存在中生代构造变形 ${ }^{[21]}$. 由于同变形变 质矿物以及相应的岩浆作用的缺乏, 本文只能通过 主断裂之间发育的中生代盆地沉积物源特征与断裂 的关系来判断盆地、断裂发育的时代(图 2(a)).

\section{1 地质体的变形与错位}

扬子西缘走滑构造带内不同时代地层的变形特 征具有比较明显的差异. 晚三叠世以前地层的褶皱 形态总体显示了隔档式褶皱样式(图 2(b)), 而且在断 裂附近还发育强烈的不对称褶皱和顺层滑动构造, 晚三叠世之后的地层变形以相对宽缓的近直立褶皱 为主, 表明扬子地块西缘在晚三叠世以前经历了强 烈的构造活动.

通过地质和地貌证据计算的扬子西缘走滑构造 带的白严纪-新生代地质体位移距离明显小于走滑构 造带的总位移距离, 表明扬子地块西缘在中生代已 经存在一定的走滑位移. 同时, 安宁河西侧的冕宁杂 岩中, 除了出露有同构造侵位的三叠纪岩浆体, 晚元 古代岩浆体中也同样存在三叠纪的独立铅石 ${ }^{[41]}$, 表 明安宁河断裂在三叠纪时期也是以走滑构造为主. 所以川滇南北向构造带内扬子地块西缘在晚三叠世侏罗纪时期已经处于走滑构造背景. 而且, 断裂系南 端均斜交于莲峰断裂, 所有断裂均没有切穿莲峰断 裂以及与莲峰断裂近平行的上三叠-侏罗系褶皱 ${ }^{2)}$. 从而表明扬子西缘走滑断裂带的形成要早于北东向 侏罗系褶皱的形成, 应在白严纪以前.

\section{2 中生代沉积盆地发育特征}

盆地与造山带之间的耦合关系及盆地沉积充填 对造山过程的响应, 已经成为人们认识造山带构造

2) 云南省地质局第二区域地质调查大队. 鲁甸幅 1:20万区域地质调查报告. 1980 
变形过程、确定变形时代的重要途径 ${ }^{[42]}$. 例如, 中国 中西部走滑-挠曲盆地的研究证实, 它们与中新生代 走滑造山作用相关 ${ }^{[43]}$.

扬子地块西缘左行走滑断裂带中发育一些中生 代沉积盆地. 这些盆地现今多为北西-南东向延伸的 独立小盆地, 整体呈雁列状排列. 在走滑断裂带北部, 盆地被限定在断层之间, 断层基本上不破坏盆地的 完整性.

盆地基底主要由震旦系、古生界组成, 盆内主要 充填物为晚三叠世-侏罗纪碎屑沉积, 晚三叠世白果 湾组和须家河组碎屑岩组成了中生代盆地最底部沉 积序列, 主要出露于盆地边缘地带. 三叠纪是扬子地 块盖层沉积的重要转折期, 中三叠世嘉陵江组为台 地边缘海相碳酸盐岩, 而晚三叠世白果湾组和须家河 组则转变为陆相碎屑沉积. 盆地底部上三叠统不整合 覆盖于晚二叠世火山岩之上, 底部以含煤的细碎屑沉 积为主, 砂岩比例较少, 往上粒度明显变粗, 以砂岩 和粗砂岩为主, 并且发育块状层理、斜层理、波痕等 沉积构造, 总体显示晚三叠世以湖相沉积为主. 上三 叠统与二叠纪玄武岩之间区域不整合接触关系, 明 确地限定盆地从晚三叠世开始发育. 晚三叠世之后, 沉积过程基本连续, 但早、中侏罗世沉积环境明显不 同. 中侏罗统底部广泛发育一套稳定的厚约 $2 \mathrm{~m}$ 的砾 岩层, 砾石以次棱角状到次圆状为主, 成分多为玄武 岩和灰岩, 反应了近距离搬运特点, 而且砾岩底部与 下侏罗统之间存在明显的冲刷面, 也是物源区具强 烈构造活动的响应. 盆地中心的中-上侏罗统主要由 灰绿-紫红色砂岩、粉砂岩和粘土岩组成, 具水平层 理、平行层理、交错层理、板状斜层理及波痕等构造, 反映了河流-湖泊沉积环境.

甘洛盆地位于扬子地块西缘左行走滑变形带中 部, 面积约 $700 \mathrm{~km}^{2}$, 呈北西-南东向分布在石棉-昭 觉断裂和汉源-甘洛断裂之间. 虽然石棉-昭觉断裂东 侧一条次级左行走滑断裂切入盆地西南缘(图 2(a)), 但是并没有破坏盆地早中生代地层的完整性.

晚三叠-早侏罗世沉积的古水流特征显示, 盆地 东部主要物质来源方向是北北东向, 北部来源于北 西和北东方向, 盆地西部则明显来源于西南侧的隆 起, 总体形成了向盆地中心汇聚的特征(图 9(a)). 盆 地中心的中-晚侏罗世沉积的古水流测量结果显示, 沉积物主要来源于盆地北西侧、西侧和东侧, 也形成 了由四周向中心汇聚的古水流特征(图 9(a)). 特别需
要注意的是, 盆地内局部隆起的二叠系周缘的中侏 罗世沉积物古水流明显背向二叠系所在的位置, 而 晚三叠世-早侏罗世沉积物古水流方向则不受二叠系 隆起的影响(图 9(a)), 表明甘洛盆地在早侏罗世以后 仍经历了构造变形. 盆地内上三叠统-下侏罗统的最 大沉积厚度位于西南部, 而中-上侏罗统的沉积厚度 最大位于西北部, 反映该盆地沉积中心的转变, 可能 与盆地周缘断裂走滑活动有关.

九襄盆地位于扬子地块西缘左行走滑剪切带北 段, 面积约 $250 \mathrm{~km}^{2}$, 盆地西南侧为汉源-甘洛断裂, 北东侧为三合-雷波断裂, 盆地东部发育完整, 西部 被汉源-甘洛断裂破坏, 晚三叠世-早侏罗世地层与 断层西南侧新元古代花岗岩直接接触. 盆地古水流 方向测量显示晚三叠世和侏罗纪的沉积物源主要来 自盆地北东和南西两个方向(图 9(b)), 而且盆地西南 侧早古生代地层中具有明显的由南西往北东逆冲的 不对称褶皱(图 7(d)), 表明盆地的形成与西南侧断裂 相关.

上述两个保存比较完整的中生代盆地的沉积相 和古流向研究表明, 扬子地块西缘发育的这些小的 中生代盆地应该是从晚三叠世开始发育的陆相盆地, 中侏罗世开始沉积环境由原来的湖相沉积为主转变 为河流相沉积为主. 尽管两个盆地的周缘缺乏具有 边缘相特征的砾岩沉积, 但是甘洛盆地和九襄盆地 的沉积相特征表明, 两个盆地经历了相同的演化过 程. 沉积物古流向测量结果表明, 两个盆地的形成相 对独立, 而且盆地沉积中心位置也存在明显的转变. 所以, 扬子地块西缘中生代盆地可能是在统一的走 滑构造背景下形成的各个独立的陆内盆地.

\section{4 讨论}

扬子地块西缘发育的总体走向北西-北北西向左 行走滑断层, 控制了一系列早中生代开始发育的沉积 盆地. 走滑断裂的断层面与擦痕统计反演的主压应力 方位为北西-南东向, 断裂早期曾经表现为由南西往 北东的逆冲. 主断层之间的岩片, 变形相对简单, 主 要为一些左行走滑断层、箱状和尖棱状褶皱等, 上三 叠统中发现的具有断坪-断坡组合指示由西往东的滑 脱变形. 扬子地块西缘早中生代左行走滑系统的确 认, 表明川滇南北向构造带在早中生代就已经开始 形成. 另外, 晚白垩世-古近纪, 松潘-甘孜地体东缘 


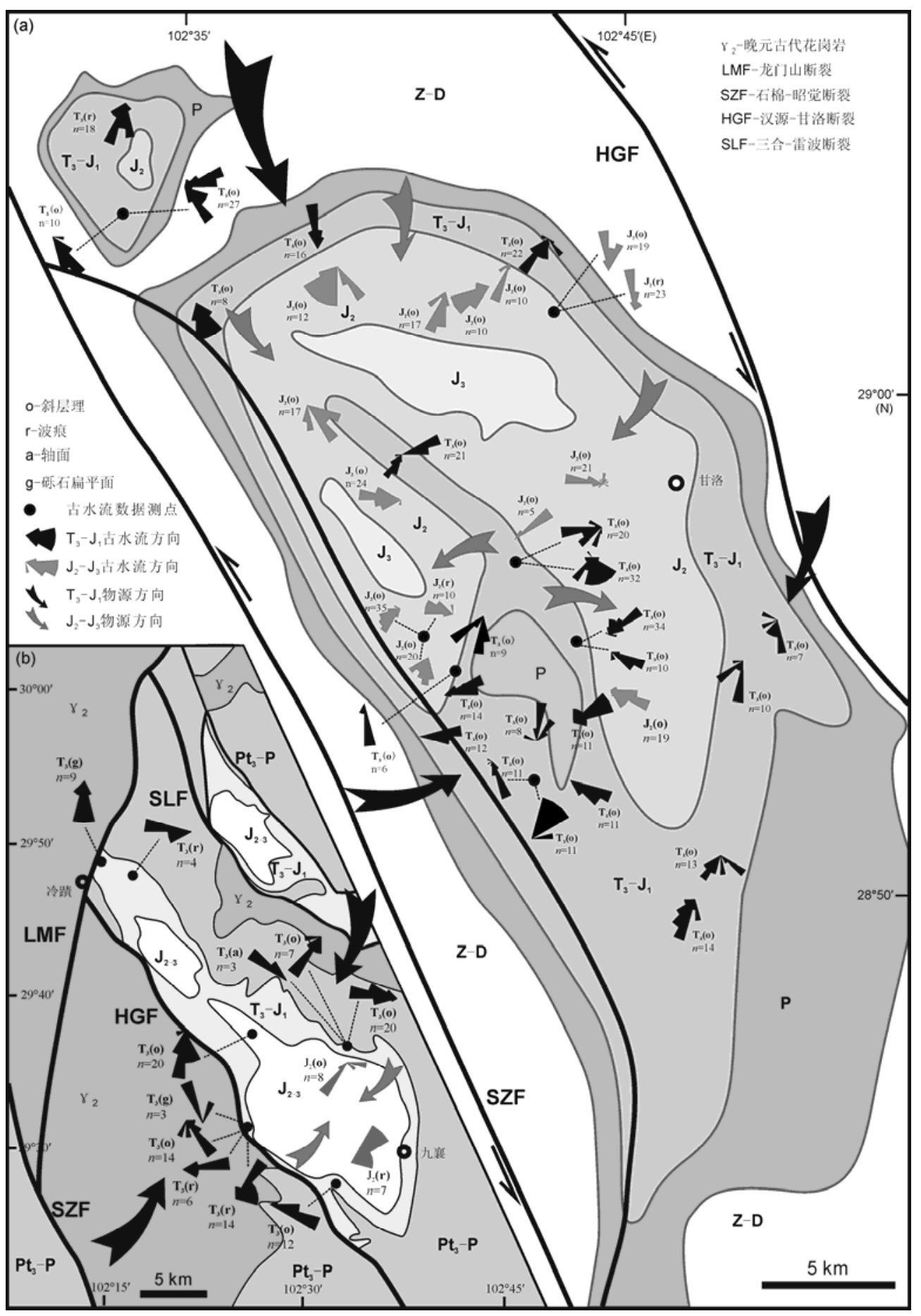

图 9 扬子地块西缘走滑断裂带内甘洛盆地(a)与九襄盆地(b)上三叠统-侏罗系沉积古水流分布特征

沿龙门山断裂带向南东逆冲在扬子地块西缘走滑断 裂带之上 ${ }^{[44]}$ 、与甘洛和九襄等中生代盆地类似的西昌 盆地中最新地层为白严系. 所以, 本文鉴定出的中生 代左行走滑变形, 可能一直持续到白严纪末.
晚三叠世, 松潘-甘孜古特提斯洋的俯冲消减, 在 龙门山构造带形成主断层北西倾的推覆构造 ${ }^{[45,46]}$, 松 潘-甘孜地体内挤压应力方位应是北东-南西向 ${ }^{[47 \sim 49]}$. 同时, 龙门山构造带在早中生代还经历了大规模的 
北东-南西向的左旋走滑 ${ }^{[48,50]}$, 体现了压剪性的变形 特征 ${ }^{[49,51]}$. 本文研究表明, 扬子地块西缘此时为北东南西向挤压形成的冲断滑脱构造. 所以, 扬子地块西 缘走滑断裂带内构造变形和应力场特征与整个川滇 南北向构造带的构造应力场也是统一的.

正如前述，川滇南北向构造带内扬子地块西缘 在早中生代所处构造环境具有两个显著特征, 即扬 子地块向北的俯冲碰撞和从三叠纪开始的顺时针旋 转. 扬子地块的顺时针旋转已经获得了很多证据, 古 地磁学研究提出在二叠纪以后发生大规模的顺时针 旋转 ${ }^{[22 ~ 54]}$, 四川盆地自三叠纪以后的顺时针旋转角 度可能达到约 $70^{\circ[55]}$, 其中晚三叠世-侏罗纪期间的 旋转量约为 $30^{\circ[56,57]}$, 并在其周缘形成了大量左行走 滑断层 ${ }^{[5]}$. 沉积学研究也证实了四川盆地相对于周边 造山带在三叠纪以后发生了大规模的顺时针旋转 ${ }^{[58]}$. 根据地幔柱岩浆迁移的轨迹也获得了相同的结论 ${ }^{[59]}$.

所以，扬子地块在晚三叠世-侏罗纪顺时针旋转 的过程中向北俯冲碰撞导致地块西缘, 特别是四川 盆地西南缘形成了左行剪切变形的应力环境, 以至 形成一系列左行走滑断层(图 10). 同时, 在左行走滑 断层发育过程中, 受扬子与㒸塘地块之间陆块碰撞 的影响, 扬子地块西缘形成了北东-南西向挤压应力 场环境, 导致古生代-中三叠世地层中的不对称褶皱、
箱状褶皱等构造变形. 所以在晚三叠-早侏罗世, 扬 子西缘与松潘-甘孜地体之间处于陆内类前陆盆地环 境，从而在这些区域性左行走滑断裂之间的相对凹 陷处，发育形成了具有独立演化过程的陆内湖相盆 地(图 10). 到中-晚侏罗世时期, 扬子地块北缘和西 缘进入以走滑为主的陆内变形阶段 ${ }^{[60]}$, 并形成盆地 沉积由湖相向河流相的转变.

由此可见，川滇南北向构造带内的走滑断裂带 和中生代盆地的形成应是扬子与其周缘块体间洋陆 俯冲碰撞和块体旋转综合作用的结果. 在这一复杂 的陆块碰撞拼贴过程中, 川滇南北向构造带扬子地 块边缘在其初始形成过程中经历了逆冲与压剪性构 造的复合作用, 并控制了晚三叠世-侏罗纪盆地的形 成. 现今南北向构造带的总体格局, 很可能是在中生 代变形基础上, 由于青藏高原向东挤出叠加了新生 代构造变形的结果.

\section{5 结论}

（1）川滇南北向构造带由扬子地块西缘左行走 滑构造带、龙门山左行走滑构造带、鲜水河左行走 滑构造带、盐源和木里逆冲推覆构造带以及楚雄盆 地等构成. 发育于扬子地块西缘的北西向左行走滑

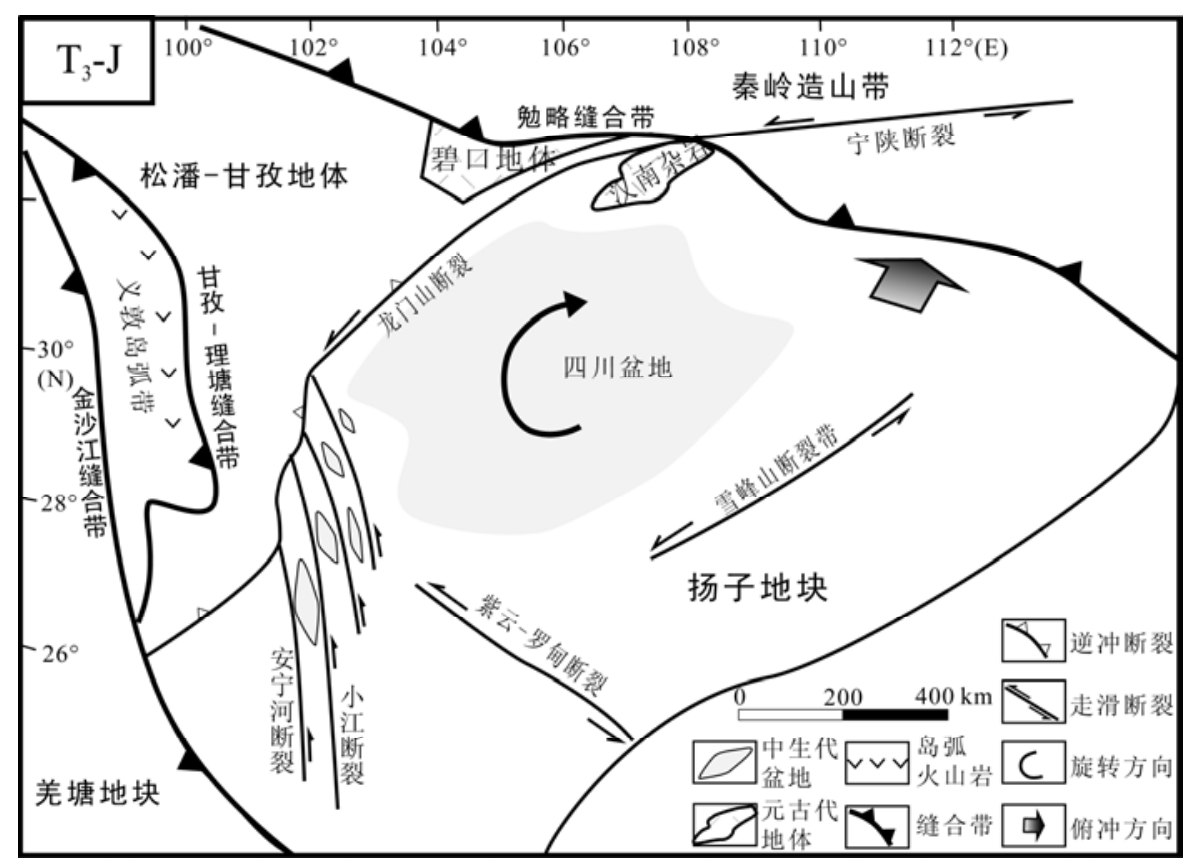

图 10 晚三叠世-侏罗纪川滇南北向构造带走滑断裂带形成模式 
断裂带, 是扬子地块在晚三叠世-侏罗纪向北俯冲碰 撞和顺时针旋转联合作用的结果, 最初发育于晚三 叠世, 并持续到白严纪末.

（2）川滇南北向构造带的形成与印支期中国南 北大陆的主体碰撞密切相关, 后来在青藏高原向东 挤出过程中叠加了强烈的新生代构造变形.
（3）扬子西缘走滑断裂带经历了两期构造叠加. 早期变形为北东-南西挤压应力场形成的逆冲断裂, 晚期北西-南东挤压应力场环境下的北西-南东向左 行走滑断裂明显叠加于早期逆冲断裂. 根据地质体 的错位关系估算, 中生代期间的位移量至少为 27 $\mathrm{km}$.

\section{致谢衰心感谢匿名评审人对论文初稿和复审稿提出的诸多建设性修改意见和建议.}

\section{参考文献}

1 袁学诚, 华九如, 邹光华. 中国地球物理图集. 北京: 地质出版社, 1996.1-200

2 Liu Y K, Chang X, He J K, et al. Three-dimensional velocity images of the crust and upper mantle beneath the north-south zone in China. Bull Seismol Soc Am, 2005, 95: 916-925

3 邱瑞照, 李廷栋, 邓晋福, 等. 中国大地构造单元新格局一从岩石圈角度的思考. 中国地质, 2006, 23: 401-410

4 张培震. 中国大陆岩石圈最新构造变动与地震灾害. 第四纪研究, 1999, 19: 404-413

5 邓起东, 张培震, 由勇康, 等. 中国活动构造基本特征. 中国科学 D 辑: 地球科学, 2002, 32: 1020-1031

6 马宗晋, 杜品仁, 洪汉净. 地球构造与动力学. 广州: 广东科技出版社, 2003. 1-564

7 丁国瑜. 中国岩石圈动力学概论. 北京：地震出版社, 1991. 1-600

8 张国伟, 郭安林, 姚安平. 中国大陆构造中的西秦岭-松潘大陆构造结. 地学前缘, 2004, 11: 23-32

9 李廷栋. 中国岩石圈构造单元. 中国地质, 2006, 33: 700-710

10 Wang E, Burchfiel B C. Late Cenozoic to Holocene deformation in southwestern Sichuan and adjacent Yunnan, China, and its role in formation of the southeastern part of the Tibetan Plateau. Geol Soc Am Bull, 2000, 112: 413-423

11 Enkelmann E, Ratschbacher L, Jonckheere R, et al. Cenozoic exhumation and deformation of northeastern Tibet and the Qinling: Is Tibetan lower crustal flow diverging around the Sichuan Basin? Geol Soc Am Bull, 2006, 118: 651-671

12 Shen J, Wang Y P, Song F M. Characteristics of the active Xiaojiang fault zone in Yunnan, China: A slip boundary for the southeastward escaping Sichuan-Yunnan block of the Tibetan Plateau. J Asian Earth Sci, 2003, 21: 1085-1096

13 张岳桥, 杨农, 孟晖, 等. 四川攀西地区晚新生代构造变形历史与隆升过程初步研究. 中国地质, 2004, 31: 23-33

14 Wilson C, Harrowfield M J, Reid A J. Brittle modification of Triassic architecture in eastern Tibet: Implications for the construction of the Cenozoic plateau. J Asian Earth Sci, 2006, 27: 341-357

15 Ouimet W B, Whipple K X, Royden L H, et al. The influence of large landslides on river incision in a transient landscape: Eastern margin of the Tibetan Plateau (Sichuan, China). Geol Soc Am Bull, 2007, 119: 1462-1476

16 张培震. 青藏高原东缘川西地区的现今构造变形、应变分配与深部动力过程. 中国科学 $\mathrm{D}$ 辑: 地球科学, 2008, 38: 1041-1056

17 颜丹平, 宋鸿林, 田竞亚. 扬子地块西缘新生代造山作用与前陆盆地构造演化. 四川地质学报, 1997, 17: 246-252

18 张国伟, 郭安林, 董云鹏, 等. 中国大陆贺兰一川滇南北构造带与青藏高原东部边界关系与动力学. 见: 吴福元, 范宏瑞, 陈福坤, 编. 全国岩石学与地球动力学研讨会, 浙江杭州, 2005. 4-6

19 王椿镛, 吴建平, 楼海, 等. 青藏高原东部壳幔速度结构和地幔变形场的研究. 地学前缘, 2006, 13: 349-359

20 Li S L, Mooney W D, Fan J C. Crustal structure of mainland China from deep seismic sounding data. Tectonophysics, 2006, 420: 239-252

21 胡健民, 孟庆任, 石玉若, 等. 松潘-甘孜地体内花岗岩铅石 SHRIMP U-Pb 定年及其构造意义. 岩石学报, 2005, 21: 867-880

22 Roger F, Calassou S, Lancelot J, et al. Miocene emplacement and deformation of the Konga-Shan granite (Xianshui-He fault zone, west Sichuan, China): Geodynamic implications. Earth Planet Sci Lett, 1995, 130: 201-216

23 许志琴, 王宗秀, 候立玮. 松潘-甘孜造山带构造研究新进展. 中国地质, 1991, 18: 14-15

24 葛肖虹. 川西盐源推覆构造的探讨. 长春地质学院学报, 1984, 14: 36-43

25 Yan D P, Zhou M F, Song H L, et al. Origin and tectonic significance of a Mesozoic multi-layer over-thrust system within the Yangtze Block (South China). Tectonophysics, 2003, 361: 239-254

26 Jia D, Wei G Q, Chen Z X, et al. Longmen Shan fold-thrust belt and its relation to the western Sichuan Basin in central China: New insights from hydrocarbon exploration. AAPG Bull, 2006, 90: 1425-1447

27 何宏林, 池田安隆, 何玉林, 等. 新生的大凉山断裂带—鲜水河-小江断裂系中段的裁弯取直. 中国科学 D 辑: 地球科学, 2008, 38: 
564-574

28 Meng Q R, Hu J M, Wang E, et al. Late Cenozoic denudation by large-magnitude landslides in the eastern edge of Tibetan Plateau. Earth Planet Sci Lett, 2006, 243: 252-267

29 Wang E, Burchfiel B C, Royden L H, et al. Late Cenozoic Xianshuihe-Xiaojiang, Red River, and Dali fault systems of southwestern Sichuan and central Yunnan, China. Geol Soc Am Special Paper, 1998, 327: 1-108

30 许志琴，侯立炜，王宗秀，等. 中国松潘-甘孜造山带的造山过程. 北京：地质出版社, 1992. 1-190

31 Roth F. A model for the present stress-field along the Xian-shui-he fault belt, northwest Sichuan, China. Tectonophysics, 1989, 167: 103-115

32 Li Y S, Shang Y Q, Wang S T. Research on the present activity and seismogenetic model of Anning River fault in the western part of Sichuan province. In: Price D G, ed. Proceedings-Sixth International Congress: International Association of Engineering Geology. Rotterdam: A A Balkema, 1990. 1655-1662

33 刘家铎, 张成江, 刘显凡, 等. 扬子地台西南缘成矿规律及找矿方向. 北京: 地质出版社, 2004. 19-35

34 朱成男, 滕德贞, 段家乐. 云南小江断裂带水平位错的测定. 云南地质, 1983, 2: 319-326

35 宋方敏, 汪一鹏, 俞维贤, 等. 小江活动断裂带. 北京: 地震出版社, 1998. 1-237

36 张国伟, 孟庆任, 于在平, 等. 秦岭造山带的造山过程及其动力学特征. 中国科学 D 辑: 地球科学, 1996, 26: 193-200

37 Meng Q R, Zhang G W. Geologic framework and tectonic evolution of the Qinling orogen, central China. Tectonophysics, 2000, 323: 183-196

38 董树文, 胡健民, 施炜, 等. 大巴山侏罗纪叠加褶皱与侏罗纪前陆. 地球学报, 2006, 27: 403-410

39 胡健民, 施炜, 渠洪杰, 等. 秦岭造山带大巴山弧形构造带中生代构造变形. 地学前缘, 2009, 16: 49-68

40 Reid A J, Wilson C, Phillips D, et al. Mesozoic cooling across the Yidun arc, central-eastern Tibetan Plateau: A reconnaissance ${ }^{40} \mathrm{Ar} /{ }^{39} \mathrm{Ar}$ study. Tectonophysics, 2005, 398: 45-66

41 陈岳龙, 罗照华, 赵俊香, 等. 从锆石 SHRIMP 年龄及岩石地球化学特征论四川冕宁康定杂岩的成因. 中国科学 D 辑: 地球科学, 2004, 34: 687-697

42 王清晨, 李忠. 盆山耦合与沉积盆地成因. 沉积学报, 2003, 21: 24-30

43 刘和甫, 夏义平, 殷进垠, 等. 走滑造山带与盆地耦合机制. 地学前缘, 1999, 6: 121-132

44 贾东, 陈竹新, 贾承造, 等. 龙门山前陆褶䏢冲断带构造解析与川西前陆盆地的发育. 高校地质学报, 2003, 9: 402-410

45 刘和甫, 梁惠社, 蔡立国, 等. 川西龙门山冲断系构造样式与前陆盆地演化. 地质学报, 1994, 68: 101-117

46 Chen S F, Wilson C J L. Emplacement of the Longmen Shan thrust-nappe belt along the eastern margin of the Tibetan Plateau. J Struct Geol, 1996, 18: 413-430

47 刘树根, 赵锡奎, 罗志立, 等. 龙门山造山带-川西前陆盆地系统构造事件研究. 成都理工学院学报, 2001, 28: 221-230

48 王二七, 孟庆任, 陈智樑, 等. 龙门山断裂带印支期左旋走滑运动及其大地构造成因. 地学前缘, 2001, 8: 375-384

49 Harrowfield M J, Wilson C J L. Indosinian deformation of the Songpan Garze fold belt, northeast Tibetan Plateau. J Struct Geol, 2005, 27: 101-117

50 Dirks P H G M, Wilson C J L, Chen S, et al. Tectonic evolution of the NE margin of the Tibetan Plateau: Evidence from the central Longmen mountains, Sichuan Province, China. J Southeast Asian Earth Sci, 1994, 9: 181-192

51 Worley B A, Wilson C J L. Deformation partitioning and foliation reactivation during transpressional orogenesis: An example from the central Longmen Shan, China. J Struct Geol, 1996, 18: 395-411

52 Enkin R J, Yang Z Y, Chen Y, et al. Paleomagnetic constraints on the geodynamic history of the major blocks of China from the Permian to the present. J Geophys Res Solid Earth, 1992, 97(B10): 13953-13989

53 Yang Z, Courtillot V, Besse J, et al. Jurassic paleomagnetic constraints on the collision of the north and south China blocks. Geophys Res Lett, 1992, 19: 577-580

54 Yokoyama M, Liu Y Y, Halim N, et al. Paleomagnetic study of upper Jurassic rocks from the Sichuan Basin: Tectonic aspects for the collision between the Yangtze Block and the North China Block. Earth Planet Sci Lett, 2001, 193: 273-285

55 王二七, 孟庆任. 对龙门山中生代和新生代构造演化的讨论. 中国科学 D 辑: 地球科学, 2008, 38: 1221-1223

56 Seguin M K, Zhai Y J. Paleomagnetic constraints on the crustal evolution of the Yangtze Block, Southeastern China. Tectonophysics, 1992, 210: 59-76

57 Gilder S A, Gill J, Coe R S, et al. Isotopic and paleomagnetic constraints on the Mesozoic tectonic evolution of south China. J Geophys Res Solid Earth, 1996, 101: 16137-16154

58 Meng Q R, Wang E, Hu J M. Mesozoic sedimentary evolution of the northwest Sichuan Basin: Implication for continued clockwise rotation of the South China block. Geol Soc Am Bull, 2005, 117: 396-410

59 张旗, 钱青, 王焰, 等. 扬子地块西南缘晚古生代基性岩浆岩的性质与古特提斯洋的演化. 岩石学报, 1999, 15: 576-583

60 Ratschbacher L, Hacker B R, Calvert A, et al. Tectonics of the Qinling (Central China): Tectonostratigraphy, geochronology, and deformation history. ectonophysics, 2003, 366: 1-53 